\title{
Fokus på selvmordsforebygging
}

Intervju med Norges Jeger- og Fiskerforbund

Norges Jeger- og Fiskerforbund (NJFF) er en landsdekkende interesseorganisasjon for jegere og fiskere i Norge. De er partipolitisk nøytrale, men har et sterkt jakt-, fiske-, og naturpolitisk engasjement i mange saker. De arrangerer også jegerprøvekurs. Forbundets våpenkonsulent og representant i våpenlovutvalget, Vidar Nilsen, ble bedt om å tenke høyt rundt selvmordsforebygging på ulike nivåer.

- Hvordan mener dere selvmordsforebyggingsperspektivet er tatt med fra våpenlovutvalgets side i innstilling til ny våpenlov?

- Våpenlovutvalgets innstilling bygger i stor grad på eksisterende våpenlovgivning, og vi mener selvmordsforebyggingsperspektivet absolutt er til stede. Først og fremst gjennom å videreføre et strengt regime for oppbevaring av våpen og ammunisjon i private hjem. Videre foreslår utvalget å innføre krav til helse, hvor egenerklæring om helse og meldeplikt for helsepersonell er aktuelle momenter. Enkelte av endringene som er foreslått av utvalget fordrer endringer i bl.a. helsepersonelloven, og er derfor ikke fullstendig utredet i Våpenlovutvalgets innstilling. Våpenlovutvalget har hatt samtaler med relevante kompetansesentre for å sikre at forebyggingsperspektivet har vært med i grunnlaget for innstillingen.

- Når det gjelder jegerprøven og jegerprøveinstruktørene - hvordan har man jobbet for å få selvmordsperspektivet og ikke minst metodesikring inn her?

- NJFF har registrert at statistikken over skyteselvdrap de siste tiårene har en påfallende sammenheng med innskjerpinger i kravene om oppbevaring av skytevåpen i godkjente våpenskap. Hovedmotivet for de strenge oppbevaringsreglene har vært å forhindre tyveri og at barn/uvedkommende får tilgang til skytevåpen. Sikker oppbevaring av skytevåpen er blant de tiltakene som også kan ha en selvmordsforebyggende effekt. Dette prøver vi å formidle videre til våre instruktører og jegerprøvekandidater.

- Hvordan er deres erfaringer med dette, hvordan blir dette mottatt?

- Vår erfaring er at informasjon og kunnskap om risikofaktorer og metodesikring knyttet til selvmord blir godt mottatt. Ikke minst gir det for mange et litt videre perspektiv knyttet til viktigheten av å følge reglene om våpenoppbevaring og det ansvaret våpeneierskap medfører.

NJFF setter pris på å kunne ha et samarbeid med kompetansemiljøer som f.eks. Nasjonalt senter for selvmordsforskning og -forebygging, slik at vi på en best mulig måte kan ivareta og informere om selvmordsforebyggende tiltak som er relevante for vår virksomhet.

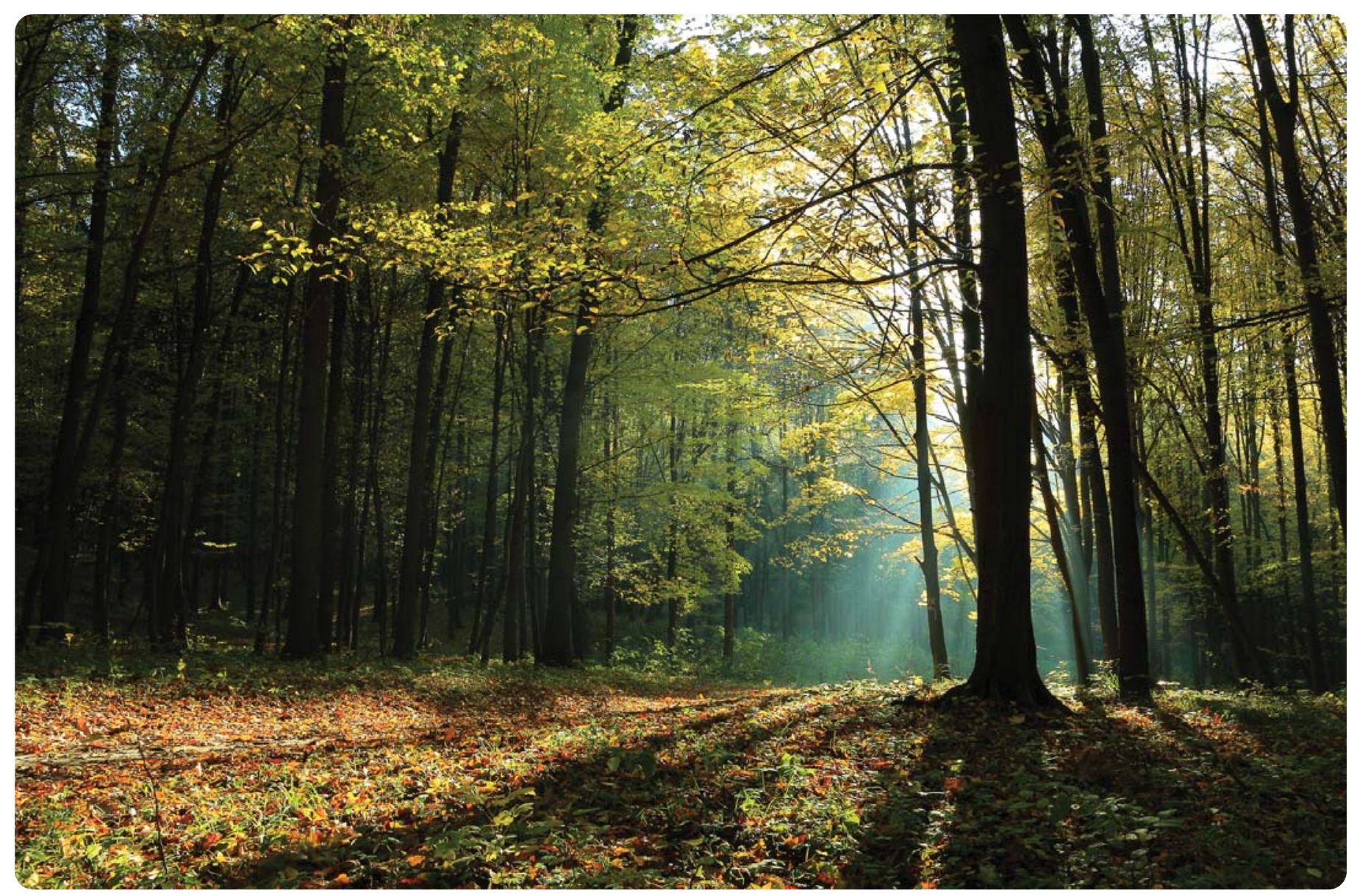

